\title{
シリコンオキシナイトライド繊維の合成とその機械的性質
}

\author{
佐 藤 光 彦・長谷川良雄*・岡 村 清 人 \\ 東北大学 金属材料研究所附属材料試験炉利用施設 \\ * (財) 特殊無機材料研究所
}

\section{Preparation of Silicon Oxynitride Fiber and Its Mechanical Properties}

\author{
Mitsuhiko SATO, Yoshio HASEGAWA* and Kiyohito OKAMURA \\ ( The Oarai Branch, The Research Institute for Iron, Steel and Other Metals, Tohoku University \\ Oarai, Higashi-Ibaraki-gun 311-13 \\ * The Research Institute for Special Inorganic Materials
}

The nitridation of polycarbosilane started at $400^{\circ}$ to $500^{\circ} \mathrm{C}$ in the heat treatment of polycarbosilane in $\mathrm{NH}_{3}$ gas and was almost completed at about $800^{\circ} \mathrm{C}$. Above $1000^{\circ} \mathrm{C}$, the obtained nitride changed from amorphous to crystalline state, and at $1400^{\circ} \mathrm{C}$, the crystalline phase was $\alpha-\mathrm{Si}_{3} \mathrm{~N}_{4}$. On the basis of the nitridation of polycarbosilane, oxidation-cured polycarbosilane fibers were heated in $\mathrm{NH}_{3}$ gas between $1000^{\circ}$ and $1400^{\circ} \mathrm{C}$ to obtain silicon oxynitride fibers. The silicon oxynitride fibers were in the amorphous state and transparent to visible light. The tensile strength and Young's modulus of the fibers obtained at $1300^{\circ} \mathrm{C}$ were $1.80 \pm 0.37 \mathrm{GPa}$ and $139 \pm 17 \mathrm{GPa}$, respectively. The fibers obtained at $1400^{\circ} \mathrm{C}$ were heat-treated between $1000^{\circ}$ and $1400^{\circ} \mathrm{C}$ in $\mathrm{Ar}$ gas and in air to examine the heat resistance of the fibers. The fibers retained their tensile strength and Young's modulus up to $1400^{\circ} \mathrm{C}$ in Ar gas and up to $1200^{\circ} \mathrm{C}$ in air.

[Received July 15, 1986]

Key-words : Polycarbosilane, Silicon nitride, Silicon oxynitride fiber, Nitridation

\section{1. 緒 言}

シリコンオキシナイトライドは耐酸化性, 耐熱衝撃性, 溶融金属に対する耐侵食性及び高温強度などが優れてお り, $\mathrm{Si}_{3} \mathrm{~N}_{4}$ や $\mathrm{SiC}$ と同様に高温構造材料として有用であ ることは良く知られている11,2). そしてこれらの柔軟な 長く細い繊維は，金属やセラミックスを母材とした複合 材料の強化材として有望である. シリコンオキシナイト ライドのウイスカーや短繊維は, $\mathrm{Si}-\mathrm{SiO}_{2}$ 系混合粉末成 形体を窒化させることによって合成されている31,4). し かしながら長繊維は著者らの知る限りではまだ得られて いない.

近年，有機金属ポリマーの前駆体を熱分解することに よってセラミック材料を合成する方法が注目されてきて おり, 各種の $\mathrm{SiC}$ 繊維, $\mathrm{Si}-\mathrm{N}-\mathrm{C}$ 系繊維及び $\mathrm{Si}_{3} \mathrm{~N}_{4}$ 材料 などが種々の有機金属ポリマーから合成されてい $3^{5) ~ 9)}$. 本研究では有機金属ポリマーの一つであるポリ カルボシランのアンモニア気流中での熱分解挙動を調 ベ, ポリカルボシランの前駆体繊維からシリコンオキシ ナイトライド繊維（ $\mathrm{Si}-\mathrm{N}-\mathrm{O}$ 繊維と略す）を合成し，そ の機械的性質について調べたので報告する.

\section{2. 実 験}

2.1 アンモニア気流中でのポリカルボシランの熱分解 本研究では, ポリシランから常圧法で合成された数平 均分子量約 2000 のポリカルボシランを使用した ${ }^{10)}$. ポ
リカルボシランを $\mathrm{Al}_{2} \mathrm{O}_{3}$ 製焼成ボートに入れ，横型管状 炬（炉内均熱部の寸法は $40 \mathrm{~mm} \phi \times 200 \mathrm{~mm}$ ) を用いて, $200 \mathrm{ml} / \mathrm{min}$ のアンモニア（純度 $99.99 \%$ ) 気流中, $100^{\circ} \mathrm{C} / \mathrm{h}$ の昇温速度で $300^{\circ} \sim 1400^{\circ} \mathrm{C}$ の $100^{\circ} \mathrm{C}$ 間隔の各 温度まで昇温し, 各温度で 1 時間保持した後室温まで冷 却して窒化生成物を得た。

\section{$2.2 \mathrm{Si}-\mathrm{N}-\mathrm{O}$ 緎維の合成}

図 1 に $\mathrm{Si}-\mathrm{N}-\mathrm{O}$ 繊維の合成過程の概略を示す。数平 均分子量が約 2000 のポリカルボシランを窒素気流中, $310^{\circ} \mathrm{C}$ に加熱後, 溶融紡糸してポリカルボシラン繊維を 得た。このポリカルボシラン繊維を空気中, 室温から

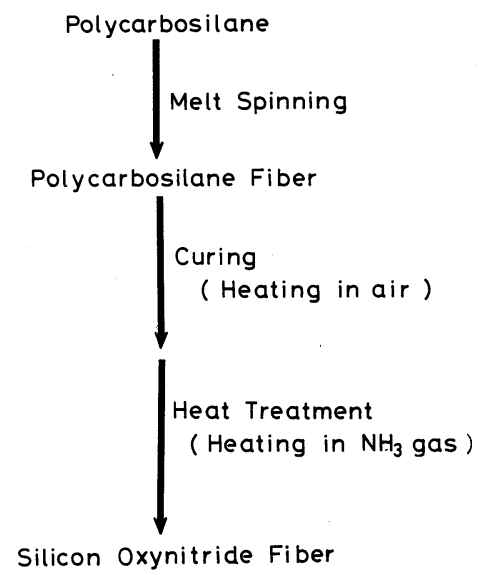

Fig. 1. Preparation method of silicon oxynitride fibers. 
$165^{\circ} \mathrm{C}$ まで 18 時間で昇温し, その温度で 1 時間保持し て不融化処理を行った.この不融化処理によってポリカ ルボシラン瀻維は酸化され，5～6 wt\% の重量増加が観 測された。不融化後のポリカルボシラン繊維を 120 〜 $150 \mathrm{ml} / \mathrm{min}$ のアンモニア（純度 $99.99 \%)$. 気流中, $100^{\circ} \mathrm{C} / \mathrm{h}$ の昇温速度で $1000^{\circ} \sim 1400^{\circ} \mathrm{C}$ の $100^{\circ} \mathrm{C}$ 間隔の 各温度まで昇温し, 各温度で 1 時間保持して $\mathrm{Si}-\mathrm{N}-\mathrm{O}$ 繊維を得た.

\section{$2.3 \mathrm{Si}-\mathrm{N}-\mathrm{O}$ 織維の耐熱試験}

2.2 節で述べた方法によって $1400^{\circ} \mathrm{C} て ゙$ 得られた $\mathrm{Si}-\mathrm{N}-\mathrm{O}$ 繊維について, 空気中及びアルゴン気流中, $300^{\circ} \mathrm{C} / \mathrm{h}$ の昇温速度で $1000^{\circ} \sim 1400^{\circ} \mathrm{C}$ の $100^{\circ} \mathrm{C}$ 間隔の 各温度まで昇温し, 各温度で 1 時間保持して室温まで冷 却した後, 室温で引張り試験を行って耐熱性を調べた。

\section{4 実験方法}

2.1 節においてアンモニア気流中で加熱して得られた ポリカルボシランの熱分解生成物について, 次に示す測 定を行いポリカルボシランの熱分解挙動を調べた.

（1）赤外吸収スペクトルは日立製作所製 285 形赤外 分光光度計を使用して, $\mathrm{KBr}$ 法で測定した. (2) 粉末 $X$ 線回折測定は理学電機製回転対陰極型 RU-200 で, $\mathrm{PG}$ 湾曲結晶モノクロメーターで単色化した $\mathrm{Cu} K \alpha$ 線を 用い, $40 \mathrm{kV}, 150 \mathrm{~mA}$ で行った.（3）各温度でポリカ ルボシランから得られた熱分解生成物の残留率は, 各熱 分解生成物の重量を室温で測定することによって求め た.（4）ポリカルボシランから得られた各熱分解生成 物についてケイ素, 窒素, 炭素及び水素の 4 元素の化学 分析を行った.

2.2 節において得られた各 $\mathrm{Si}-\mathrm{N}-\mathrm{O}$ 瀻維及び 2.3 節に おいて熱処理を行った各 $\mathrm{Si}-\mathrm{N}-\mathrm{O}$ 繊維について，次に 示す測定を行い構造及び機械的特性を調べた.

(1) 密度は $\mathrm{CHBr}_{3} / \mathrm{CCl}_{4}$ の浸せき液による密度勾配 管法によって測定した し，減圧下で脱気した後に測定に供した。（2）引張り 強度及びヤング率は, 東洋ボールドウィン製万能引張り 試験機テンシロン UTM- II - 20 を使用し，室温で単瀻 維試験法により引張り試験を行って求めた ${ }^{11)}$. 測定条件 は試料長が $25 \mathrm{~mm}$, 引張り速度が $2 \mathrm{~mm} / \mathrm{min}$ であった。 繊維径は測微顕微鏡によって測定した。引張り試験は 各々 30 本の試料について行い, その結果の平均值と標 準偏差を求めて評価した（ 3 ) 繊維の X 線回折測定は 2.1 節において得られた熱分解生成物の粉末 $X$ 線回折 測定と同様の条件で行った。ただし，測定は緎維状の試 料で行った.（4）繊維断面のX $\mathrm{X}$ 線マイクロアナリシス は島津製作所製 EMX-SM を使用し，加速電圧は 10 $\mathrm{kV}$, 吸収電流は $1 \times 10^{-8} \mathrm{~A}$ で行った。（6）繊維の表面 観察は日本電子製走査型電子影微鏡 JSM-U 3 を用いて 行った.

\section{3. 結果及び考察}

\section{1 ポリカルボシランの窒化反応}

アンモニア気流中, 各温度で加熱して得られたポリカ ルボシランの熱分解生成物の重量残留率を図 2 に, 赤外 吸収スペクトルを図 3 に，そして化学分析結果を表 1 に 原子比で示す. 本研究で使用したポリカルボシランの化

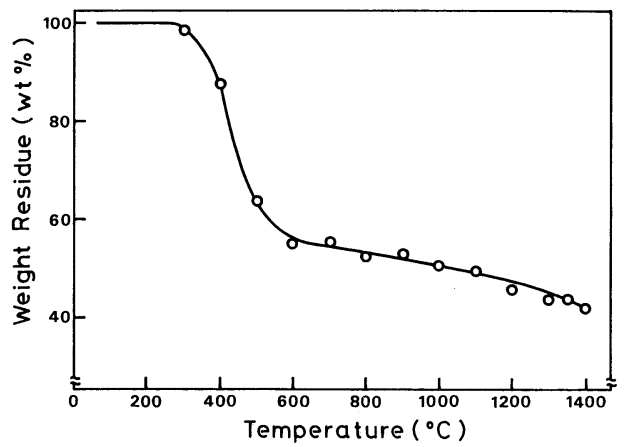

Fig. 2. TG curve of polycarbosilane in $\mathrm{NH}_{3}$ gas.

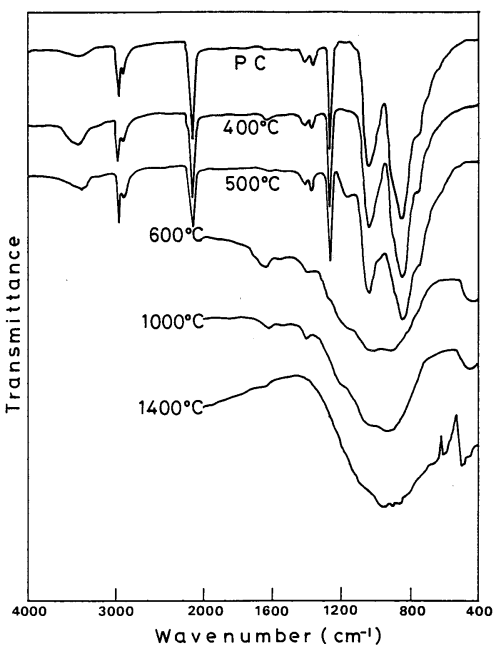

Fig. 3. Infrared spectra of nitrides obtained from polycarbosilane $(\mathrm{PC})$ at each temperature.

Table 1. Compositions (atomic ratio) of nitrides obtained from polycarbosilane (PC) at each temperature.

\begin{tabular}{|c|c|}
\hline Sample & Empirical Formula \\
\hline$P \quad C$ & $\mathrm{Si}_{i} \mathrm{~N}_{0.00} \mathrm{C}_{1.93} \mathrm{H}_{4.71} \mathrm{O}_{0.01}$ \\
\hline $400^{\circ} \mathrm{C}$ & Si $\mathrm{N}_{0.02} \mathrm{C}_{1.94} \mathrm{H}_{4.69}$ \\
\hline $500^{\circ} \mathrm{C}$ & $\mathrm{Si} \mathrm{N}_{0.14} \mathrm{C}_{1.87} \mathrm{H}_{4.56}$ \\
\hline $600^{\circ} \mathrm{C}$ & $\mathrm{Si} \mathrm{N}_{1.31} \mathrm{C}_{0.36} \mathrm{H}_{1.24}$ \\
\hline $800^{\circ} \mathrm{C}$ & Si $N_{1.26} C_{0.04} H_{0.19}$ \\
\hline $1000^{\circ} \mathrm{C}$ & Si $N_{1.29} C_{0.03} H_{0.19}$ \\
\hline $1200^{\circ} \mathrm{C}$ & Si $N_{1.26} C_{0.01} H_{0.15}$ \\
\hline $1400^{\circ} \mathrm{C}$ & Si $N_{1.24} C_{0.00} H_{0.00}$ \\
\hline
\end{tabular}


学組成は $\mathrm{SiC}_{1.93} \mathrm{H}_{4.71}$ で窒素は含まれていない.このポ リカルボシランをアンモニア気流中で加熱すると, $300^{\circ} \mathrm{C}$ 付近から重量減少が始まるが， $400^{\circ} \mathrm{C}$ までは化学 組成に変化がないことから，この段階での重量減少は低 分子量のポリカルボシランの揮発によるものと推定され る ${ }^{12)}$. その後 $400^{\circ}$ から $600^{\circ} \mathrm{C}$ にかけて大きな重量減少 がある. 化学組成においてもこの温度範囲で窒素が増加 し，炭素及び水素が大きく減少している. そして $800^{\circ} \mathrm{C}$ では炭素はほとんど存在していない，赤外吸収スペクト ルも $400^{\circ}$ から $600^{\circ} \mathrm{C}$ にかけて大きく変化しており, こ の変化は既に報告されているポリカルボシランの真空中 での熱分解の場合に比べて非常に大きく，ポリカルボシ ランがアンモニア気流中で急激に熱分解したことがわか る ${ }^{12)}$.また $500^{\circ} \mathrm{C}$ におけるスペクトルで $3390 \mathrm{~cm}^{-1}$, $1175 \mathrm{~cm}^{-1}$, 及び $930 \mathrm{~cm}^{-1}$ 付近の吸収が強く現れており, Si-NH-Si 結合が形成されたためだと考えられる ${ }^{13)}$. $800^{\circ} \mathrm{C}$ 以上では大きな変化はなく, 温度上昇に伴ってわ ずかに残留する炭素及び水素が減少し, 徐々に残留率も 低下する. $1400^{\circ} \mathrm{C}$ で得られた熱分解生成物はケイ素と 窒素から構成され, その組成は $\mathrm{Si}_{3} \mathrm{~N}_{3.72}$ となりほぼ窒化 ケイ素 $\left(\mathrm{Si}_{3} \mathrm{~N}_{4}\right)$ の組成であった.

以上のことから，ポリカルボシランをアンモニア気流 中で加熱すると, $400^{\circ} \sim 500^{\circ} \mathrm{C}$ で熱分解に伴って窒化反 応が始まり, その後急激に反応が進行し, $800^{\circ} \mathrm{C}$ で反応

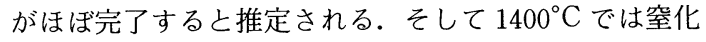
ケイ素が得られることがわかった.

図 4 にアンモニア気流中, $1000^{\circ} \sim 1400^{\circ} \mathrm{C}$ で得られた ポリカルボシランの熱分解生成物の X 線回折パターン を示す. $1300^{\circ} \mathrm{C}$ までは回折パターンはブロードであり, 熱分解生成物が非晶質であることを示している.しかし，

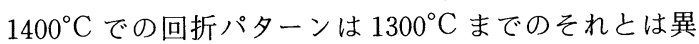

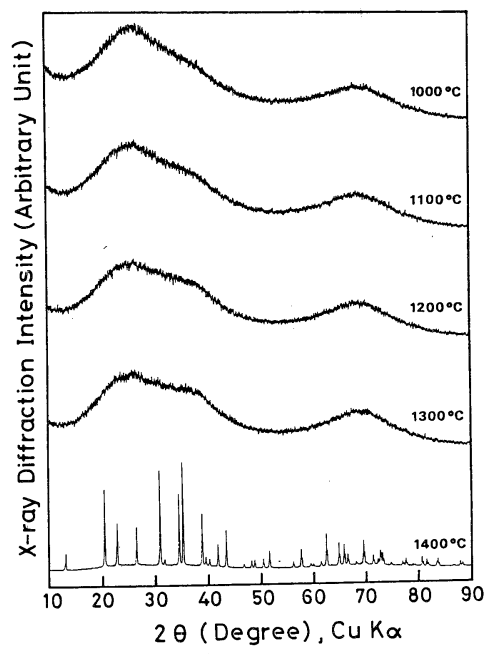

Fig. 4. X-ray diffraction patterns of nitrides obtained by the nitridation of polycarbosilane.
なり， $1400^{\circ} \mathrm{C}$ で得られた熱分解生成物が結晶化した $\alpha$ $\mathrm{Si}_{3} \mathrm{~N}_{4}$ であることを示している.このことは赤外吸収ス ペクトルとも一致している ${ }^{14)}$.

窒素を含まない有機ケイ素ポリマーの前駆体をアンモ ニア気流中で加熱すると，その熱分解過程に伴って $800^{\circ} \mathrm{C}$ 以下で窒化反応が起こり, 生成物として窒化ケイ 素が残ることは本研究により初めて明らかになった。ポ リカルボシランのアンモニア気流中での熱分解挙動につ いては，現在さらにくわしく調査検討中である.

\section{$3.2 \mathrm{Si}-\mathrm{N}-\mathrm{O}$ 織維}

ポリカルボシラン繊維が空気中, 低温で加熱されると, ポリカルボシラン分子が酸素により架橋され不融化され る.このように酸素が導入されたポリカルボシラン瀻維 がアンモニア気流中, $1000^{\circ} \sim 1400^{\circ} \mathrm{C}$ で熱処理され，直 径約 $13 \mu \mathrm{m}$ の無機繊維が得られた。この繊維は無色で可 視光に対しては透明であった. 図 5 に $1400^{\circ} \mathrm{C}$ で得られ た繊維の断面の X 線マイクロアナライザー (EPMA) によるケイ素, 窒素, 酸素及び炭素の分析結果を示す. この図から, 得られた繊維はケイ素, 窒素及び酸素で構 成されており,炭素はほとんど存在しないことがわかる. またこの測定の際の各原子の $K \alpha$ 線の強度から計算した 原子比は $\mathrm{SiN}_{1.15} \mathrm{O}_{0.47}$ であり, 化学分析結果の $\mathrm{SiNO}_{0.52}$ ともほぼ一致していた。

図 6 に各合成温度で得られた無機繊維の $\mathrm{X}$ 線回折パ ターンを示す.すべての回折パターンはブロードであり， 得られた無機繊維はいずれの温度でも非晶質であること を示しているが, 温度の上昇に伴い徐々にではあるが結

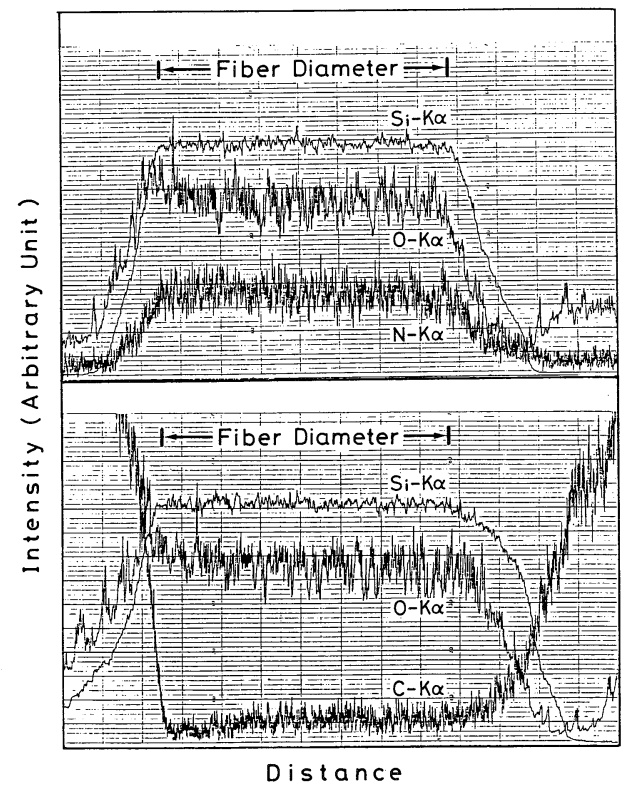

Fig. 5. X-ray microprobe analysis for $\mathrm{Si}, \mathrm{O}, \mathrm{N}$ and $\mathrm{C}$ content of cross-sectional surface of silicon oxynitride fiber obtained at $1400^{\circ} \mathrm{C}$. 
晶化が進んでいることがわかる ${ }^{15)}$.

以上の結果及び 3.1 節で示したポリカルボシランのア ンモニア気流中での熱分解挙動から, 本研究で得られた 無機繊維は非晶質の $\mathrm{Si}-\mathrm{N}-\mathrm{O}$ 繊維であることがわかっ た. また Si-N-O 繊維中の酸素は, 合成過程の不融化 処理によってポリカルボシラン繊維中に導入された酸素 であると推定される.

図 7 に $\mathrm{Si}-\mathrm{N}-\mathrm{O}$ 繊維の密度, 引張り強度及びヤング 率と合成温度との関係を示す。密度及びヤング率は合成 温度の上昇に伴って増加しており， $1400^{\circ} \mathrm{C}$ では各々

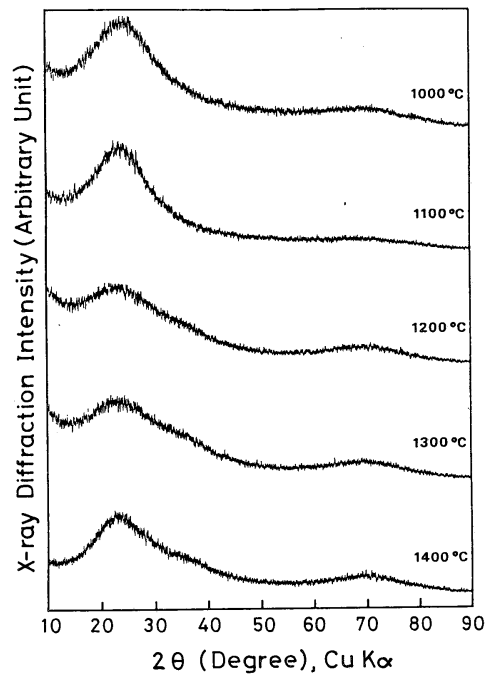

Fig. 6. X-ray diffraction patterns of silicon oxynitride fibers obtained at $1000^{\circ}$ to $1400^{\circ} \mathrm{C}$.

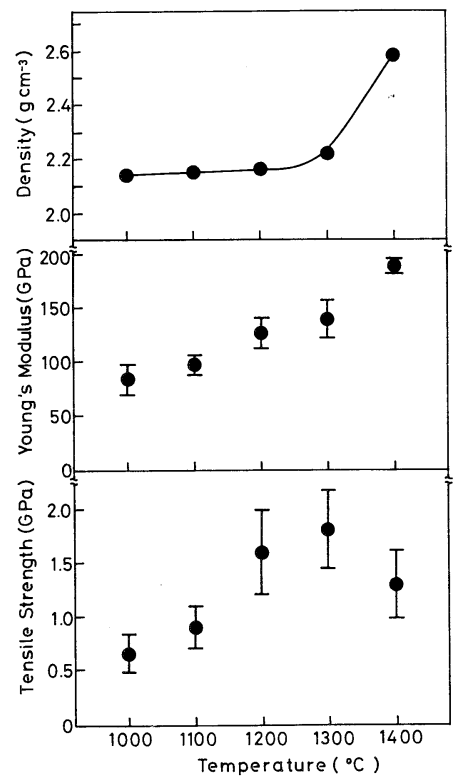

Fig. 7. Density, Young's modulus and tensile strength of silicon oxynitride fibers obtained at $1000^{\circ}$ to $1400^{\circ} \mathrm{C}$.
$2.59 \mathrm{~g} / \mathrm{cm}^{3}, 188 \pm 7 \mathrm{GPa}$ を示した. 引張り強度は $1300^{\circ} \mathrm{C}$ まで温度の上昇に伴い増加し $1300^{\circ} \mathrm{C}$ で $1.80 \pm$ $0.37 \mathrm{GPa}$ を示したが, $1400^{\circ} \mathrm{C}$ では減少し $1.29 \pm 0.32$ $\mathrm{GPa}$ を示した。

$\mathrm{Si}_{2} \mathrm{~N}_{2} \mathrm{O}$ は大気圧の窒素気流中, $1500^{\circ} \mathrm{C}$ 以上に加熱す ると $\mathrm{Si}_{3} \mathrm{~N}_{4}, \mathrm{SiO}$ (ガス) 及び $\mathrm{N}_{2}$ (ガス) に分解するこ とはよく知られている ${ }^{16)}$. 本研究の $\mathrm{Si}-\mathrm{N}-\mathrm{O}$ 繊維で, $1300^{\circ}$ から $1400^{\circ} \mathrm{C}$ にかけての密度及びヤング率の増加, 引張り強度の減少は，この熱分解に関係があると考えら れる.

\section{3. $3 \mathrm{Si}-\mathrm{N}-\mathrm{O}$ 織維の耐熱性}

本研究で合成した $\mathrm{Si}-\mathrm{N}-\mathrm{O}$ 繊維の中で $1400^{\circ} \mathrm{C}$ で得ら

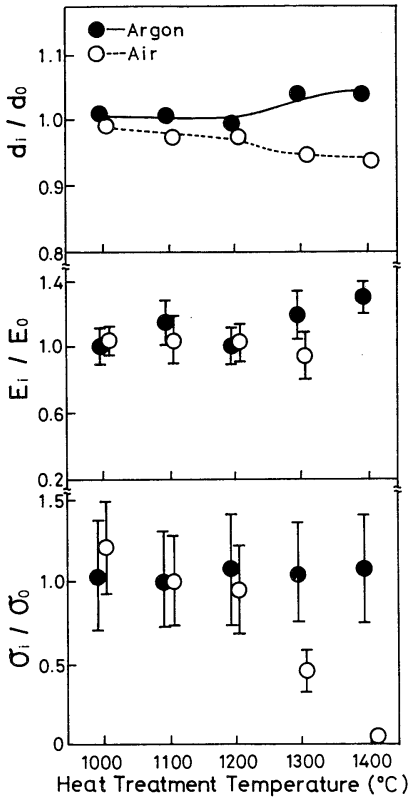

Fig. 8. Variations in density $\left(d_{\mathrm{i}} / d_{0}\right)$, Young's modulus $\left(E_{\mathrm{i}} / E_{0}\right)$ and tensile strength $\left(\sigma_{\mathrm{i}} / \sigma_{0}\right)$ of silicon oxynitride fibers heat-treated at $1000^{\circ}$ to $1400^{\circ} \mathrm{C}$ in Ar gas and in air.
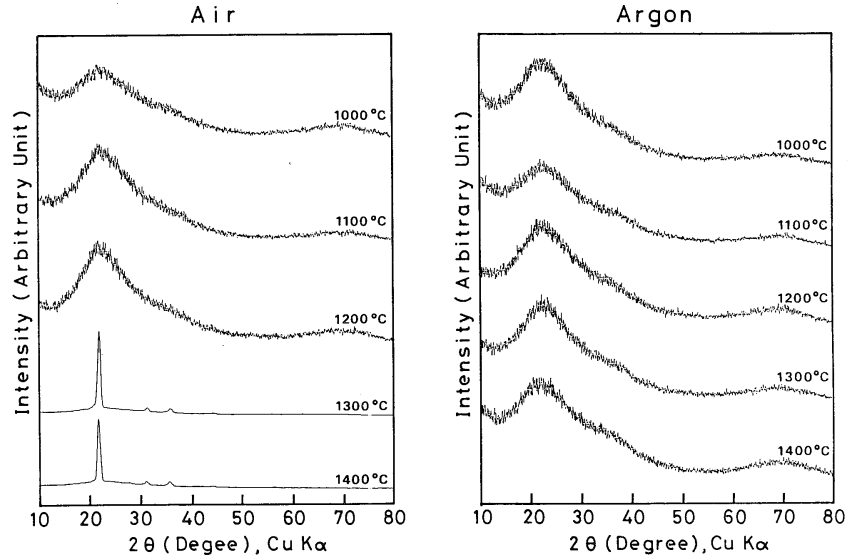

Fig. 9. X-ray diffraction patterns of silicon oxynitride fibers heat-treated at $1000^{\circ}$ to $1400^{\circ} \mathrm{C}$ in $\mathrm{Ar}$ gas and in air. 


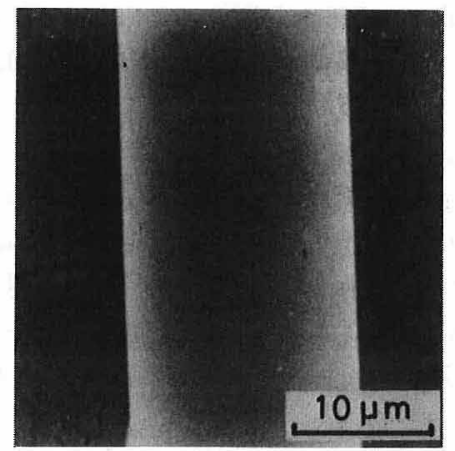

Si-N-O Fiber

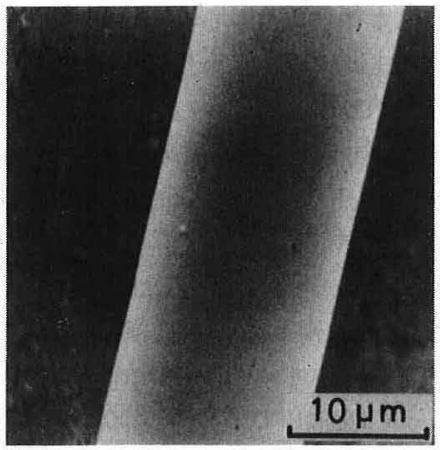

Argon, $1400^{\circ} \mathrm{C}$

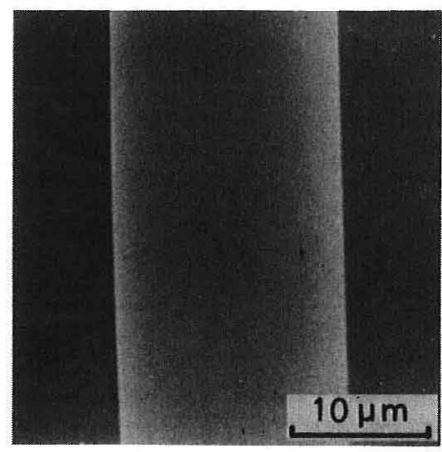

A i r. $1200^{\circ} \mathrm{C}$

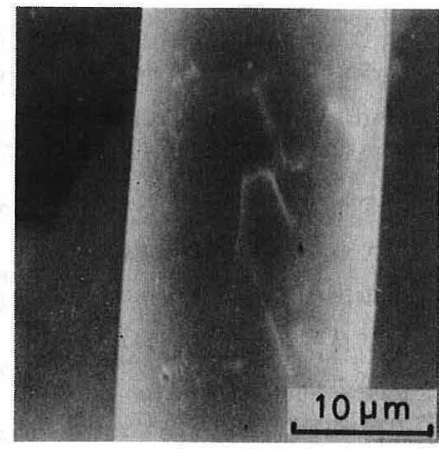

A i r. $1300^{\circ} \mathrm{C}$

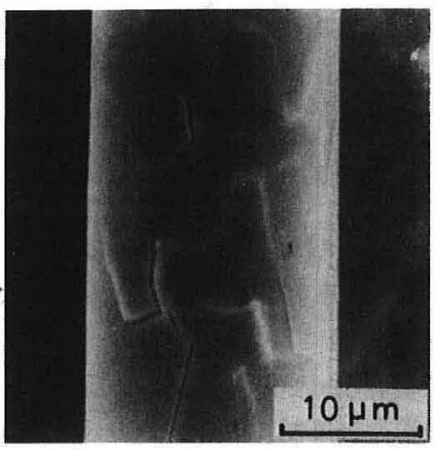

A ir, $1400^{\circ} \mathrm{C}$

Fig. 10. Scanning electron micrographs of silicon oxynitride fibers.

れた繊維について，空気中及びアルゴン気流中で熱処理 してその耐熱性を調べた. 引張り強度，ヤング率及び密 度については, 熱処理前の強度, ヤング率及び密度の值 をそれぞれ $\sigma_{0}, E_{0}$ 及び $d_{0}$ とし，熱処理後の值を $\sigma_{\mathrm{i}}$, $E_{\mathrm{i}}$ 及び $d_{\mathrm{i}}$ として, 熱処理による変化をそれぞれの比 $\sigma_{\mathrm{i}} / \sigma_{0}, E_{\mathrm{i}} / E_{0}$ 及び $d_{\mathrm{i}} / d_{0}$ で評価した.

図 8 に密度, 引張り強度及びヤング率の変化 $d_{1} / d_{0}$, $\sigma_{\mathrm{i}} / \sigma_{0}$ 及び $E_{\mathrm{i}} / E_{0}$ と処理温度の関係を, 図 9 に耐熱試験 後の各䋐維の X 線回折パターンを, 図 10 に耐熱試験後 の繊維の表面の走査型電子顕微鏡写真を示す.

\subsection{1 アルゴン気流中での耐熱性}

アルゴン気流中では $\mathrm{Si}-\mathrm{N}-\mathrm{O}$ 繊維の引張り強度は $1400^{\circ} \mathrm{C}$ までほとんど変化しなかったが，ヤング率及び 密度は処理温度が $1300^{\circ}$ 及び $1400^{\circ} \mathrm{C}$ の場合においてや や増加する傾向を示した. また， $1400^{\circ} \mathrm{C}$ まで処理して も瀻維表面に大きな変化はみられなかった，X線回折 パターンにおいて, $1000^{\circ} \mathrm{C}$ の場合と $1300^{\circ}$ 及び $1400^{\circ} \mathrm{C}$ の場合とを比較すると, 高温でわずかに結晶化が進んだ ことがわかる. $1300^{\circ}$ 及び $1400^{\circ} \mathrm{C}$ での密度及びヤング 率の増加はおそらくこの結晶化の影響を受けていると考 えられる.

\subsection{2 空気中での耐熱性}

空気中では $\mathrm{Si}-\mathrm{N}-\mathrm{O}$ 繊維の引張り強度は $1200^{\circ} \mathrm{C}$ まで
は大きな変化はなく, $1300^{\circ} \mathrm{C}$ で大きな減少を示した. ヤング率に大きな変化はなかったが, 密度は引張り強度 亡同様に $1300^{\circ}$ 及び $1400^{\circ} \mathrm{C}$ で減少傾向を示した. X 線 回折パターンから熱処理後の繊維は $1200^{\circ} \mathrm{C}$ までは非晶 質であるが, $1300^{\circ} \mathrm{C}$ ではアルゴン気流中で熱処理した 場合とは異なり $\alpha$-クリストバライトが析出したことが わかる. また熱処理後の繊維表面の観察から, $1200^{\circ} \mathrm{C}$ までは繊維表面に変化はみられなかったが， $1300^{\circ}$ 及び $1400^{\circ} \mathrm{C}$ で多数のクラックが生成したことが明らかに なった. 熱処理温度が $1300^{\circ} \mathrm{C}$ 以上での密度の減少は繊 維が酸化され多量の酸化物が生成したためだと考えら れ, 引張り強度の大きな減少は生成した酸化物が結晶化 し, 多量の $\alpha$-クリストバライト結晶が析出したためで あり,さらにはこの急激な結晶化によって瀻維表面に多 くのクラックが生成したためだと考えられる.

\section{4. 総 括}

ポリカルボシランのアンモニア気流中での熱分解挙動 を調べ，その結果に基づいて無機繊維を合成し，得られ た繊維の特性を調べた結果，以下のことが明らかになっ た.

（1）ポリカルボシランをアンモニア気流中で加熱す ると, $400^{\circ} \mathrm{C}$ 以上で熱分解に伴って窒化反応が始まり, 
$800^{\circ} \mathrm{C}$ でほぼ完了する. 得られた熱分解生成物は $1000^{\circ} \mathrm{C}$ では非晶質であるが, $1400^{\circ} \mathrm{C}$ では $\alpha-\mathrm{Si}_{3} \mathrm{~N}_{4}$ で あった.

（2）ポリカルボシラン瀻維を空気中で不融化した 後, アンモニア気流中, $1000^{\circ} \mathrm{C}$ 以上に加熱する之高強 度を有する $\mathrm{Si}-\mathrm{N}-\mathrm{O}$ 繊維が得られた。この $\mathrm{Si}-\mathrm{N}-\mathrm{O}$ 繊 維は非晶質で，可視光に対しては透明であった。

（３） $1400^{\circ} \mathrm{C}$ で合成された $\mathrm{Si}-\mathrm{N}-\mathrm{O}$ 繊維は，空気中 では $1200^{\circ} \mathrm{C}$ まで，アルゴン気流中では $1400^{\circ} \mathrm{C}$ まで熱 処理しても強度及びヤング率に大きな変化はなかった。

謝辞 EPMAによる元素分析に当たり, 標準試料として $\mathrm{SiC}$ 及び $\mathrm{Si}_{3} \mathrm{~N}$ 、の単結晶を提供して下さった無機材質研究所の 猪股吉三博士，並びに実際の測定に当たり多大の援助をして下 さった東北大学金属材料研究所の天野忠昭博士，同研究所の我 妻文彦氏に深く感謝致します。

\section{文献}

1）鈴木弘茂, 保坂卓男, 鵼協, 75, 111-19 (1967).
2) M.E. Washburn, Am. Ceram. Soc. Bull., 46, 667-71 (1967).

3）東 伸行, 村瀬嘉夫, 窯協, 87, 545-46 (1979).

4）東 伸行, 山田 留, 窯協, 88, 658-65 (1980).

5) K. J. Wynne and R.W. Rice, Ann. Rev. Mater. Sci., 14, 297-334 (1984).

6) R. H. Baney, Polymer Preprints, 25, 2-3 (1984).

7) R. West, I. Nozue, X.H. Zhang and P. Trefonas, Polymer Preprints, 25, 4-5 (1984).

8) B. G. Penn, F.E. Ledbetter III, J. M. Clemons and J.G. Daniels, J. Appl. Polym. Sci., 27, 3751-61 (1982).

9) D. Seyferth, G. H. Wiseman and C. Prud'homme, J. Am. Ceram. Soc., 66, C 13-14 (1983).

10) S. Yajima, Am. Ceram. Soc. Bull., 62, 893-915 (1983).

11）日本工業規格, JIS-R 7601, 「炭素繊維試験方法」.

12) Y. Hasegawa and K. Okamura, J. Mater. Sci., 18, 3633-48 (1983):

13) A. L. Smith, "Analysis of Silicones", John Wiley \& Sons (1974).

14) N. Wada, S. A. Solin, J. Wong and S. Prochazka, J. Non-Cryst. Solids, 43, 7-15 (1981).

15) K. Okamura, M. Sato, Y. Hasegawa and T. Amano, Chem. Lett., No. 12, 2059-60 (1984).

16）猪股吉三，窯協，82，522-26 (1974). 